\title{
SPOTKANIE STAROŻYTNEGO CHRZEŚCIJAŃSTWA Z FILOZOFIĄ GRECKA (W CZASACH JUSTYNA MĘCZENNIKA I KLEMENSA ALEKSANDRYJSKIEGO)
}

\section{Pytanie o duchowy sens greckiej filozofii}

Dla wielu wyznawców określonych religii, zwłaszcza tych skonkretyzowanych historycznie i kulturowo w postaci w spójnego i wyczerpującego doktrynalnie systemu, istnienie innych, w gruncie rzeczy porównywalnych pod wieloma względami, systemów religijnych stanowi zwykle mniejszy lub większy problem, i to problem przeważnie nie tylko teoretyczny, lecz również egzystencjalny, bo dotyczący nie tyle sensowności takich czy innych kwestii filozoficznych czy teologicznych, stojących za daną religią, ile prawdziwości i sensowności wyznawanej samej religii. Jest to przeto problem, który domaga się rozwiązania na poziomie ludzkiego doświadczenia egzystencjalnego, choć oczywiście takie czy inne sugestie pojawiające się na poziomie filozoficznej czy teologicznej teorii mogą bez wątpienia przybliżyć owo rozwiązanie. ${ }^{1}$

1 O stosunku chrześcijaństwa do innych religii współczesnych traktuje dokument Soboru Watykańskiego II Nostra aetate (Declaratio de Ecclesiae habitudine ad religiones non christianas), który ustawia religie „niechrześcijańskie” na wspólnej drodze do tego samego Boga i próbuje w nich dostrzec uczestnika wspólnego Objawienia, którego światłem jest Jezus Chrystus. Zob. J a n P a w e ł II, Encyklika Redemptor Misio, Libreria Editrice Vaticana 1990; por. R. B a r t n i c k i, W. K a w e k i (red.), Chrześcijaństwo a kultura, Warszawa 2006; H. B ü r k le, Człowiek w poszukiwaniu Boga: Problem różnych tradycji, tłum. M.E. K o w a l s k a, Bydgoszcz 2001, s. 83-88; K. B u k ow s k i, Religie świata wobec chrześcijaństwa, Kraków 1999; W. C h r o s t o w s k i, Bóg, Biblia, Mesjasz, Warszawa 2007, s. 434-462; P. K a c z m a r e k, Intuicje mesjańskie różnych wierzeń a osoba Jezusa 
Taki właśnie problem stanął przed wyznawcami chrześcijaństwa u jego początków w stosunku do greckiej kultury duchowej, podówczas jeszcze całkowicie ,pogańskiej”, a przede wszystkim w stosunku filozofii greckiej, która, jak wiemy, nie dość, że była niezwykle atrakcyjna pod wieloma względami, to na dodatek (podobnie jak chrześcijaństwo i niektóre ówczesne kulty misteryjne ${ }^{2}$ ) bardzo mocno wchodziła w sfery duchowe i moralne ludzkiej egzystencji, odpowiadając niemal na wszystkie pytanie egzystencjalne, jak ludzie zwykli byli stawiać (w związku z tymi moralnymi i duchowymi aspektami ludzkiego życia). ${ }^{3}$ Szczególnego znaczenia nabrał w II stuleciu, gdy

Chrystusa, Studia Loviaensia. Łowickie Studia Teologiczne 15/2013, s. 213-224; K. K o ś c i e l n i a k, Chrześcijaństwo w spotkaniu z religiami świata, Kraków 2002; K. A m s t r o n g, Historia Boga. 4000 lat dziejów Boga, tłum. B. C e n d r o w s k a, Warszawa 1995; E. S a k o w i c z, Papież Benedykt XIV wobec islamu, Studia Loviaensia. Łowickie Studia Teologiczne 15/2013, s. 107-123; H. S k i e r k ow s k i (red.), Chrześcijaństwo w kontekście judaizmu i islamu, Lumen Fidei 2, Warszawa 2003.

2 Zob. W. B u r k e r t, Starożytne kulty misteryjne, tłum. K. B i e la w s k i, Bydgoszcz 2001.

3 O duchowych aspektach filozofii starożytnej zob. P. H a d ot, Czym jest filozofia starożytna, tłum. P. D o m a ń s k i, Warszawa 2000; t e n ż e, Filozofia jako ćwiczenie duchowe, tłum. P. D o m a ń s k i, Warszawa 1992. Zob. też K. A 1 b e r t, Griechische Religion und platonische Philosophie, Hamburg 1980. (polskie wydanie dzieł K. Alberta, Studia o historii filozofii, tłum. B. B a r a n, J. M a r z ę c k i, Warszawa 2006). Mistyczne aspekty filozofii greckiej pokazuje O. C a s e 1, De Philosophorum Graecorum silentio mystico, Berlin 1967; W. J a e g e r, Teologia wczesnych filozofów greckich, tłum. J. W o c i a 1, Kraków 2007. Motywy duchowe w filozofii greckiej, takie jak wtajemniczenia, oczyszczenia, chociaż w kontekstach wychowawczo-politycznych pojawiają się też w t e n ż e, Paideia. Formowanie się człowieka greckiego, tłum. M. P l e z i a, Warszawa 2001 (zwł. s. 760, 1140, 1041). O wpływach religijnych, zwłaszcza orfickich, w filozofii greckiej pisze również w swoim fundamentalnym dziele G. R e a le, Historia filozofii starożytnej, tłum. E.I. Z i e l i ń s k i, t. I, Lublin 1993. Z polskich autorów zob. A. K r o k i e w i c z, Zarys filozofii greckiej. Od Talesa do Platona, Warszawa 1971; D. D e m b i ń s k a - S i u r y, Człowiek szuka człowieka. O początkach greckiej refleksji filozoficznej, Warszawa 1991; J. D o m a ń s k i, Metamorfozy pojęcia filozofii, Warszawa 1996; K. P a w ł o w s k i, Misteria i filozofia. Misteryjne oblicze filozofii greckiej, Lublin 2007. 
chrześcijaństwo osiągnęło poziom doktrynalny porównywalny z poziomem filozofii greckiej, zwłaszcza takich jej nurtów, jak platonizm, który w wersji mocno uduchowionej i wręcz mistycznej odżywa mniej więcej w tym okresie, gdy rodzi się chrześcijaństwo, a swoje apogeum przeżywa mniej więcej w połowie II w. po Chr., a więc wtedy, gdy chrześcijaństwo potrafi się już wyrazić jako rozwinięta filozofia, porównywalna z filozofią dawnych i współczesnych mu myślicieli „pogańskich”. Nic dziwnego, że ówcześni intelektualiści chrześcijańscy, sami wykształceni na filozofii greckiej, będą musieli podjąć problem tej filozofii i jej stosunku do chrześcijaństwa („filozofii” Chrystusa), zwłaszcza gdy zauważono, że pod wieloma względami, także pod względem duchowym, jest ona bliska chrześcijaństwu.

Widać to zwłaszcza w dziełach Klemensa, Greka z Aleksandrii, dobrze obeznanego ze starogrecką filozofią, nauczyciela w aleksandryjskiej Szkole Katechetycznej, autora słynnych Kobierców, Zachęty dla Greków i Wychowawcy. Szczególnie interesujące pod tym względem są jego Kobierce, w których odbijają się wszystkie lęki i wątpliwości chrześcijan. Z jednej strony była to obawa o czystość wiary. Wszak filozofia Greków to jednak, mówiąc językiem biblijnym, „mądrość tego świata” i do tego jeszcze mądrość pogańska. Z drugiej - niepokój, by nie utracić czegoś, co wydawało się mimo wszystko (mimo tego, że powstało w zupełnie obcej tradycji religijnej) niezwykle szlachetne, a nawet pociągające. $Z$ jednej strony był to więc lęk przed czymś, co mogłoby zaszkodzić w jakiś sposób wierze chrześcijańskiej, co jednak jest bardzo atrakcyjne pod wieloma względami i przez to jeszcze bardziej niebezpieczne. Z drugiej - wątpliwości, by nie zaniechać i utracić czegoś, co wydaje się nie tylko piękne, ale nade wszystko cenne, a do tego pod wieloma względami jakby bliskie chrześcijaństwu i filozofii Chrystusa. To ostatnie było powodem szczególnego niepokoju. Wychodziło na to, że ci ,pogańscy” Grecy jakby poznali prawdy, które przecież dopiero chrześcijanom objawił Jezus Chrystus? By znaleźć wytłumaczenie tej osobliwej i, co tu kryć, trochę gorszącej dla niektórych chrześcijan, zbieżności niektórych nauk (zwłaszcza moralnych, ale nie tylko), głoszonych przez pogańskich filozofów, z nauką (filozofią, jak niektórzy 
będą mówić) Jezusa z Nazaretu, którą ten objawił swoim uczniom, myśliciele chrześcijańscy uciekali się do różnych teorii. Niektórzy z nich zadowalali się dość popularną w owych czasach, a wysnutą najprawdopodobniej jeszcze przez żydowskiego intelektualistę Arystobulosa, a potem skwapliwie podjętą przez Filona z Aleksandrii, a za nim przez wielu chrześcijan, teorią kradzieży. ${ }^{4}$ Według tej teorii, dawni mędrcy greccy skopiowali, czyli po prostu ukradli swoje nauki, zwłaszcza moralne i teologiczne, ze Starego Testamentu. ${ }^{5}$ W ten sposób Platon, bo on był poczytywany za największego z tych greckich mędrców, stał się, jak pisze Klemens Aleksandryjski, kimś w rodzaju Mojżesza Greków. ${ }^{6}$

Inni chrześcijanie byli jednak skłonni uwierzyć, że pogańscy Grecy, a przynajmniej niektórzy z nich, mieli dostęp do wiedzy objawionej, pośredni za pośrednictwem Biblii, albo nawet bezpośredni na zasadzie objawienia naturalnego. Jednak czym miałoby być to naturalne objawienie, tego już nie byli pewni. Jedni z nich uważali, że zawiera się ono po prostu w samym poznaniu rozumowym, które samo w sobie ma jakoby moc poznania pewnych prawd z porządku nadprzyrodzonego w sposób naturalny. Objawienie „naturalne” polegałoby tu zatem tylko na tym, że to właśnie Bóg dopuścił, by wszyscy ludzie, także poganie, mogli te prawdy poznać swoim naturalnym rozumem (w świetle swego naturalnego rozumu). Inni sądzili, że wszyscy ludzie, a więc i poganie, mają udział w prawdach objawionych, które Bóg zakodował w ludzkiej duszy. Co wrażliwsi greccy filozofowie i mędrcy potrafili te prawdy odczytać. Żeby to wyjaśnić odwoływano się też stoickiej nauki o Logosie i o logoi spermatikoi

4 G. R e a l e, Historia filozofii starożytnej, t. IV, s. 275; H. i M. S i m o n, Filozofia żydowska, tłum. T.G. P s z c z ół k o w s k i, Warszawa 1990, s. 25-28. Zob. wstęp tłumacza w Fil on z A le k s a d ri i, Pisma, t. I, tłum. L. J o a c h i m ow i c z, Warszawa 1986, s. 10.

Zob. K le m e n s, Kobierce, I 66, 1-73, 1; I 148, 1-150, 5; I 165,1 - 166,1; I 176, 1-3; II 92,1; V 89, 1 -140, 1; VI 4, 1 - 42, 1; t e n ż e, Zachęta do filozofii, VI 70-71; por. O r y ge ne s, Przeciw Celsusowi, IV 39.

${ }^{6}$ K 1 e m e n s, Kobierce, I 150, 4; I 165, 1 - 166, 2. Niezależnie od tego, Klemens pomawia owych greckich mędrców, czyli filozofów, o wynalezienie herezji. 
(„racjach nasiennych”) zakodowanych w ludzkich rozumach, logosach stanowiących część Logosu świata. Ten pogląd głosił m.in. jeden z najwybitniejszych pisarzy i apologetów chrześcijańskich tego okresu, Justyn Męczennik, który gotów był takich pogan, którzy zdolni byli w ten sposób poznać cząstkę prawdy i dzięki temu żyć zgodnie z Logosem, uważać za chrześcijan (nawet gdyby w oczach innych uchodzili za ateistów), uznając zarazem wszystko, co dobre w ich nauczaniu za swoiste dziedzictwo (własność) chrześcijan: „Ci, co wiedli życie z Słowem w zgodne, są chrześcijanami, chociażby uchodzili za ateuszów. (...) Każdy z nich bowiem z rozsianego Słowa Bożego widział tylko cząstkę, w sobie kiełkującą, i tyle też tylko mówił prawdy. A ponieważ w rzeczach zasadniczych oni nawet sami z sobą stawali w sprzeczności, tedy rzecz oczywista, że nie mieli jasnego zrozumienia, ani wiedzy niewzruszonej. A zatem wszystko, co w nich dobrego, to własność chrześcijan. Albowiem po Bogu czcimy i miłujemy Słowo, pochodzące od Boga niezrodzonego i niewysłowionego, jako że dla nas stało się człowiekiem, by i w naszych cierpieniach wziąć udział i nas uleczyć. Pisarze zaś mogli widzieć prawdę, aczkolwiek niewyraźnie, dzięki nasieniu Słowa, które w nich już z natury złożone leżało".

W Dialogu z żydem Tryfonem, w którym o tym mówi, Justyn opisał własną drogę do chrześcijaństwa, przedstawiając zarazem, czym jest według niego chrześcijaństwo w stosunku do greckiej filozofii. Justyn

7 J u s t y n Mę c z e n n i k, Apologia, I 46,3 oraz II 13,3-6, tłum. A. L i s i e c k i; t e n ż e, Apologia. Dialog z Żydem Tryfonem, tłum. A. L i s i e c k i, Poznań 1926, s. 53, 93. Por. H. B ü r k l e, Człowiek w poszukiwaniu Boga: Problem różnych tradycji, s. 46. Por. R.M. L e s z c z y ń s k i, Starożytna koncepcja Logosu i jej wptyw na myśl wczesnego chrześcijaństwa, Warszawa 2003, s. 214-255; W. J a e g e r, Wczesne chrześcijaństwo i grecka paideia, tłum. K. B i e l a w s k i, Bydgoszcz 2002, s. 48-52; H. C h a d w i c k, Myśl wczesnochrześcijańska a tradycja klasyczna, tłum. P. S i e j k o w s k i, Poznań 2000, s. 17-25; M. S i m o n, Cywilizacja wczesnego chrześcijaństwa. I-IV w., tłum. E. B ą k o w s k a, Warszawa 1979, s. 143-148, 150; B. A 1 t a n e r, A. S t u i b e r, Patrologia. Życie, pisma i nauka Ojców Kościoła, tłum. P. P a c h c i a r e k, Warszawa 1990, s. 128-134; J.N.D. K e 11 y, Poczatki doktryny chrześcijańskiej, tłum. E. S t a n u 1 a, Warszawa 1988, s. 80-84, 115. 
nie miał wątpliwości, że jest ono jej uzupełnieniem, i to uzupełnieniem nadprzyrodzonym. To, czego tak gorliwie szukał u greckich filozofów i w różnych ówczesnych szkołach filozoficznych, znalazł dopiero w filozofii Jezusa Chrystusa, w którą wtajemniczył go jakiś starzec - ubogi i prosty człowiek, i zupełnie niewykształcony, który jednak swoją Chrystusową mądrością prześcignął daleko mędrców pogańskich, u których Justyn wcześniej pobierał nauki. Tym samym jeszcze raz się okazało, że Prawda, ale ta ,prawdziwa”, która nie tylko tłumaczy, ale i wypełnia ludzkie życie, sprawiając, że zyskuje ono nadprzyrodzony sens, jest skromna i, po ludzku mówiąc, najczęściej bardzo nieatrakcyjna, i nie ma nic wspólnego z ,prawdami” wielkiego świata. Owi mędrcy pogańscy, u których wcześniej Justyn terminował, nie byli w stanie pokazać mu prostej drogi do upragnionej przezeń mądrości, w której zrozumiałby i siebie, i cały świat w jednej perspektywie. Uczynił to dopiero ów skromny starzec. W filozofii, ujawnionej mu przez tego starca, tą perspektywą okazał się Jezus Chrystus. ${ }^{8}$

Dla samego Justyna droga, którą przebył od mądrości ujawniającej się w filozofii greckiej do Mądrości wcielonej w Chrystusie, była obrazem drogi, którą, w jego przekonaniu, przebyła cała ludzkość: od mądrości pogańskiej do mądrości chrześcijańskiej, ucieleśnionej i żywej w Chrystusie Jezusie, chrześcijańskim Logosie, który od początku świata w nim żyje i tworzy. Święty Justyn był jednym z tych, którzy dostrzegali swoistą zbieżność między filozofią grecką i wiarą (filozofią) chrześcijańską, widząc w tej ostatniej kontynuację tej pierwszej, a ściślej - kontynuację i wypełnienie, za pośrednictwem Chrystusowego objawienia, prawd ujawnionych już w tej pierwszej. Tę zbieżność tłumaczył, wspomnianą już, ideą Logosu - tego samego Logosu, o którym uczyli stoicy w swojej filozofii, i zarazem tego samego, o którym pisał św. Jan Ewangelista w Prologu swojej Ewangelii. Justyn nie miał wątpliwości, że tym Logosem (Logosem Greków i Logosem Ewangelii św. Jana) był Jezus Chrystus. Jezus Chrystus był wcielonym Logosem dla całej ludzkości. I w ten sposób,

8 W ówczesnej literaturze chrześcijańskiej sam Jezus Chrystus często nazywany jest Drogą i Prawdą. 
w przekonaniu Justyna, w myśli filozoficznej Greków zajaśniało to światło, którego źródłem jest Logos - ten sam, który potem wcielił się w Jezusa Chrystusa. Oczywiście pełnym blaskiem zajaśniało owo światło dopiero w objawieniu chrześcijańskim, którym znowu jest Jezus Chrystus - Słowo Boże. Tym samym nauczanie Chrystusa wyjaśnia i uzupełnia to, czego nauczali filozofowie pogańscy, ale zarazem tkwi zalążkowo w ich nauczaniu. Justyn nie omieszka nawet dodać, że filozoficzna myśl tych Greków jest w gruncie rzeczy w swym charakterze chrześcijańska i dlatego chrześcijanie są jej prawowitymi dziedzicami. Tak oto pojawiła się słynna idea praeparatio evangelica, ${ }^{9}$ odnoszona do filozofii greckiej, pojętej jako zapowiedź i przed-nauczanie „chrześcijańskiej filozofii” ucieleśnionej w Jezusie Chrystusie, wcielonym Logosie. W ten sposób Justyn dowartościował filozofię grecką w oczach samych chrześcijan, a chrześcijaństwo w oczach pogańskich Greków. Pozwoli to myślicielom chrześcijańskim zaadaptować to, co najwartościowsze w kulturze greckiej, do kultury chrześcijańskiej, a Grekom - niemal bezboleśnie przyjąć chrześcijaństwo jako coś bliskiego ich kulturze duchowej.

Podobne impresje na temat Logosu i filozofii greckiej znajdujemy u wspomnianego już Klemensa Aleksandryjskiego. U Klemensa Chrystus - Logos - Słowo jawi się jako Nauczyciel i Pedagog. ${ }^{10}$ Tu znowu filozofia Greków znajduje swoje spełnienie i wypełnienie w Chrystusie Ewangelii i wiary chrześcijan. Chrystus ma być tym żywym Logosem, który nauczał Greków w ich filozofii: „Przed przyjściem na świat Pana filozofia była niezbędna dla Hellenów, aby ich poprowadzić ku sprawiedliwości. Teraz natomiast przydaje się do tego, aby ich prowadzić

9 Ten termin rozsławi swoim dziełem Euzebiusz z Cezarei, który tak właśnie zatytułował jedno ze swoich dzieł - Praeparatio evangelica.

${ }_{10}$ K l e m e n s, Wychowawca, księga I: 1.1-3.9; 6. 25, 31; 7. 53; 12. 96, 100. Por. R.M. L e s z c z y ń s k i, Starożytna koncepcja Logosu i jej wpływ na myśl wczesnego chrześcijaństwa, s. 313-377; H. C h a d w i c k, Myśl wczesnochrześcijańska a tradycja klasyczna, s. 41-63; W. J a e g e r, Wczesne chrześcijaństwo i grecka paideia, s. 75-78; M. S i m o n, Cywilizacja wczesnego chrześcijaństwa. I-IV w., s. 180-185; G. A. M a lo n e y, Chrystus kosmiczny. Od Pawła do Teilharda, Warszawa 1986, s. $102-108$. 
ku bojaźni Bożej. Stanowi więc wstępne przygotowanie do wiary dla tych umysłów, które pragną ją zdobyć przez dowody. «Bo noga twoja jak mówi pismo - nie zawadzi o nic» (Ks. Prz. 3, 23), jeśli Opatrzności powierzasz wszystko, co dobre, bez względu na to, czy pochodzi ono od Hellenów, czy od nas. Wszelkiego bowiem dobra sprawcą jest tylko Bóg, w jednym przypadku bezpośrednio i pierwszoplanowo, jak w odniesieniu do Starego i Nowego Testamentu, w innych pośrednio i przez następstwa, jak w zastosowaniu do filozofii. Być może nawet Hellenom bezpośrednio i celowo, zanim jeszcze Pan ich powołał. Bo przecież i ona prowadziła żywioł helleński do Chrystusa, podobnie jak Prawo prowadziło do Niego Hebrajczyków. A więc filozofia pełni funkcję przygotowawczą, toruje drogę temu, którego Chrystus z kolei doprowadza do doskonałości". ${ }^{11}$

Filozofia grecka ma swoje wypełnienie wpierw w Prawach żydów, a potem w słowie Ewangelii. ${ }^{12}$ Klemens Aleksandryjski wyprowadził z tego ważny wniosek o możliwości a nawet potrzebie interpretacji zawartości chrześcijańskiego objawienia za pomocą środków wypracowanych przez filozofów greckich, które pozwalają odkryć w tym objawieniu prawdziwą filozofię chrześcijańską - tę, do której niejako zmierzała filozofia grecka.

Klemens Aleksandryjski, podobnie jak Justyn Męczennik, był umysłem bardzo chłonnym i otwartym na grecką filozofię, czego dowodem są jego dzieła, w których roi się od cytatów z greckiej filozofii. Klemens również uwierzył, że filozofia grecka dla pogan była czymś w rodzaju „przygotowania do Ewangelii” (w języku łacińskim właśnie praeparatio evangelica, termin przejęty i rozpropagowany zwłaszcza przez Euzebiusza z Cezarei, który tak właśnie zatytułuje jedno ze swoich dzieł). ${ }^{13}$ To dzięki swojej filozofii Grecy

11 K l e me n s, Kobierce, I 28, 1-4, tłum. J. N i e m i r s k a - P l i s z c z y ń s k a; zob. też I 19, 1 - 21, 3; I 32, 4; I 57, 1-6; VI 149, 2; VI 154, 1-4.

12 Tamże, I 97, 1-98, 4;

13 Tamże, I 28,1-5; I 97,1 - 99,3; Szerzej na temat praeparatio evangelica zob. J. P e li k a n, Powstanie wspólnej tradycji, tłum. M. Hö ff n e r, Kraków 2008, s. 11-71. 
mogli z bez trudu przyjąć Ewangelię, rozpoznając w niej Prawdę zarodkowo zasianą już w tej filozofii. Jednakowoż, według Klemensa, pogańska filozofia grecka, która przygotowała Greków na przyjęcie „filozofii” Chrystusa, może pełnić tę funkcję również wobec samych chrześcijan - może uzdatnić ich na przyjęcie prawd Chrystusowych, w których znajduje ona swoje spełnienie. ${ }^{14}$ Dodajmy w tym miejscu, że Klemens samą filozofię, jako taką, pojmował nie tylko w sensie czysto intelektualnym i poznawczym, lecz także moralnym, jako swego rodzaju formację moralną i duchową. ${ }^{15}$ Co więcej, moralny i duchowy wymiar filozofii wydaje się dlań ważniejszy niż czysto poznawczy. Zresztą Klemens jest zdania, że „prawdziwym poznaniem jest dopiero stan bezgrzeszności od samego początku". ${ }^{16}$

A powołując się na znany motyw biblijny, pisze w swoich Kobiercach, że łatwiej wielbłądowi przejść przez ucho igielne, niż bogatemu stać się filozofem. ${ }^{17}$

Biorąc pod uwagę moralny i duchowy aspekt filozofii, Klemens znajduje miejsce dla niej miejsce także wychowaniu chrześcijańskim. Filozofia może tu pełnić, według niego, rolę służebną. Zarazem filozofia, a zwłaszcza filozofia Platona, dzięki swemu potencjałowi intelektualnemu i duchowemu, może być czymś w rodzaju służebnicy teologii. Wyostrzając i wysubtelniać umysły wiernych, może ich przygotować do pełnego zrozumienia prawd objawionych. Jest to możliwe, gdyż ona sama mocno czerpała z objawionych nauk Mojżesza. Klemens wprawdzie odrzuca pogląd, jakoby greccy filozofowie mieli dostąpić specjalnie dla nich zgotowanego objawienia, przyznaje im jednak możliwość boskiego natchnienia: „W ogóle Pitagoras i jego uczniowie, a także Platon, najbardziej zbliżeni byli do Prawodawcy, jak to można wywnioskować $\mathrm{z}$ ich pouczeń. A idąc za jakimś trafnym

14 K 1 e me n s, Kobierce, I 28; 1-5; I 97,1 - 99, 4.

15 Widać to w całej twórczości Klemensa; zob. tamże, I 30,1; I 33, 1-6; I 55,1; VII 3,2. Por. J. W o j t c z a k, Stosunek Klemensa Aleksandryjskiego do filozofii wedtug ,Stromata”, Studia Theologica Varsaviensia 9 (1971) z. 1, s. 263-288.

16 K 1 e m e n s, Kobierce, II 2, 1.

17 Tamże, II 22,4. 
natchnieniem wieszczym, nie bez pomocy Boga samego, uzyskiwali pewną zbieżność z wypowiedziami proroków; badając zaś prawdę na różnych odcinkach i na różne sposoby, uczcili ją nazwami przejrzystymi i nieodbiegającymi od właściwej oceny rzeczywistości. Uchwycili bowiem intuicyjnie kontakt $\mathrm{z}$ istotą prawdy". ${ }^{18}$

Oczywiście Prawda, o której tu mowa, i do której zmierzali ci filozofowie pod wpływem Boskiego natchnienia, w pełni ujawniła się dopiero w nauce Jezusa Chrystusa: „Dopiero gdy Słońce zostało ogłoszone, wtedy rozbłysło już w pełni całe to święte światło". ${ }^{19}$

Zdaniem Klemensa, pełna i ostateczna prawda znalazła swego nauczyciela dopiero w Jezusie Chrystusie. W nauce Chrystusa ukazało się w pełni to, co w filozofii było ledwie zarysowane. Dopiero w Nim objawiła się ,,pełnia Bożej mądrości”. ${ }^{20}$ Filozofia jedynie do niej przygotowuje i na tym polega jej rola jako swego rodzaju praeparatio evangelica, którą może pełnić także, nieco paradoksalnie, także wobec samych chrześcijan.

Wypada w tym miejscu dodać, że nie wszyscy intelektualiści chrześcijańscy byli tak otwarci na grecką filozofię, jak Justyn Męczennik czy Klemens z Aleksandrii. Niektórzy byli wobec niej bardzo krytyczni. Należał do nich m.in. Tacjan, który uzna ją za dzieło samego szatana. Rygoryzm Tacjana doprowadzi go wpierw do walentynizmu, a w końcu do założonej przez siebie sekty enkratytów. ${ }^{21}$ Podobnie negatywny stosunek do pogańskiej filozofii miał wykształcony na greckiej i rzymskiej literaturze Tertulian, który

18 Tamże, V 29, 2-5.

19 Tamże, V 29, 6; por. H. B ü r k l e, Człowiek w poszukiwaniu Boga: Problem różnych tradycji, s. 21-22.

${ }_{20} \mathrm{~K}$ l e m e n s, Kobierce, I 28, 4; V 29, 6.

${ }^{21}$ E.R. D o d d s, Pogaństwo i chrześcijaństwo w okresie niepokoju. Niektóre aspekty doświadczenia religijnego od Marka Aureliusza do Konstantyna Wielkiego, tłum. J. P a r t y k a, Kraków 2004, s. 103; R.M. L e s z c z y ń s k i, Starożytna koncepcja Logosu i jej wpływ na myśl wczesnego chrześcijaństwa, s. 235-244; W. J a e g e r, Wczesne chrześcijaństwo i grecka paideia, s. 54-55; M. S i m o n, Cywilizacja wczesnego chrześcijaństwa. I-IV w., s. 150; J. P e l i k a n, Powstanie wspólnej tradycji, s. 36. 
uznał filozofię grecką za dzieło demonów, a filozofów nazwał patriarchami herezji. ${ }^{22}$ Rygoryzm doprowadzi go do seksty montanistów. ${ }^{23}$

Jednak zwolenników zachowania pogańskiej filozofii greckiej i zaadaptowania jej do chrześcijaństwa było zdecydowanie więcej. Było to zupełnie zrozumiałe. Wszak większość chrześcijańskich intelektualistów kształciła się właśnie w szkołach „pogańskich”. Grecka filozofia zachowana została głównie w chrześcijaństwie wschodnim, ale przeniknęła również do chrześcijaństwa zachodniego. Opierając się na niej, chrześcijańscy myśliciele sformułowali chrześcijańską teologię. Niemałą rolę odegrali tu wspomniani apologeci chrześcijańscy, którzy do obrony chrześcijan i drogich im ideałów wykorzystali wiele idei wypracowanych w filozofii greckiej. Niektórzy z nich, świadomi swojej metody, ilustrowali swoje postępowanie biblijnym obrazem ucieczki Izraelitów z Egiptu (z Księgi Wyjścia), którzy przed swoją ucieczką z niewoli egipskiej ograbili swoich ciemiężców ze złota. ${ }^{24}$ W celu usprawiedliwienia biblijnych żydów, dodawali czasem, że owo egipskie bogactwo było jednak dziełem niewolniczej pracy samych Izraelitów, a zatem niejako ich prawowitą własnością. Ów motyw, podobnie jak motyw uprowadzonej branki z Księgi Powtórzonego Prawa), powraca dość często w pismach chrześcijańskich. Stanie się nawet, jeśli tak można powiedzieć, modelowym sposobem podejścia chrześcijańskich myślicieli do filozofii pogańskiej. ${ }^{25}$ To pozwoli im przede wszystkim zaadaptować do chrześcijaństwa, formującego się na poziomie dojrzałej doktryny teologicznej, najbliższe mu myśli

22 Tertuli a n, Oduszy, 3.

23 F. C o ple s t o n, Historia filozofii, t. II, tłum. S. Z a l e w s k i, Warszawa 2000, s. 30 .

${ }^{24}$ Chodzi o słynny motyw ,złupienia Egipcjan” obecny w biblijnej Księdze Wyjścia 11, 7.

25 Sam motyw „złupienia Egipcjan”, podobnie jak motyw „uprowadzonej branki”, jako literacki topos będzie pojawiał się w literaturze chrześcijańskiej jeszcze wiele razy i w różnych kontekstach, także w oficjalnych pismach papieży, np. w liście Grzegorza IX z 1228 r. skierowanym do wykładowców paryskich, a nawet w L e o n XIII, Aeterni Patris, tłum. K. P a wło w s k i, Komorów 2000, s. $17-18$. 
i idee tej filozofii, którą będą traktować jako własne, intelektualne dziedzictwo. ${ }^{26}$

Klemens i Justyn nie byli jedynymi chrześcijańskimi myślicielami, którzy podjęli problem greckiej tradycji. Należał do ich również następca Klemensa Aleksandryjskiego w szkole katechetycznej w Aleksandrii, wielki teolog i filozof chrześcijaństwa, Orygenes (185/6-254/5). Także u niego kluczową rolę odgrywa idea Logosu-Chrystusa. ${ }^{27}$ Podejmuje ją również duchowy spadkobierca Orygenesa, św. Grzegorz z Nyssy (ok. 335-395). ${ }^{28}$ Idea Chrystusa-Logosu

26 Zob.przyp. 4.

27 Zob. O r y g e nes, O zasadach, II 1-13; t e n ż e, Duch i ogień, wybór i wprow. H. Urs v o n B a 1 t h a s a r, Kraków-Warszawa, s. 61-63, 81-85, 89-92. Zob. H. C r o u z e 1, Orygenes, tłum. J. M a r g a ń s k i, Kraków 2004, s. 102-105, 149-154; A. L o u th, Poczatki mistyki chrześcijańskiej, Kraków 1997, s. 73-98; E. D o d d s, Pogaństwo i chrześcijaństwo w okresie niepokoju. Niektóre aspekty doświadczenia religijnego od Marka Aureliusza do Konstantyna Wielkiego, s. 101-126; W. J a e g e r, Wczesne chrześcijaństwo i grecka paideia, s. 79-81; H. C h a dw i c k, Myśl wczesnochrześcijańska a tradycja klasyczna, s. 85-91; M. S i m o n, Cywilizacja wczesnego chrześcijaństwa. I-IV w., s. 186-191; G. A. M a lo n e y, Chrystus kosmiczny. Od Pawła do Teilharda, s. 110-117. Orygenes pojmuje Logos jako przedwieczne Słowo Boga i przedwieczną Mądrość, która legła u początku stworzenia, i która zawiera w sobie całą prawdę stworzenia. Przede wszystkim Logos jest Słowem wcielonym w Jezusie Chrystusie, który jest Synem Boga Ojca, osobą Trójcy świętej. Jezus Chrystus jest tym Logosem - Słowem Bożym, z którym spotykamy się w Ewangelii, i którego żywej obecności doświadczamy w naszym życiu. On jest centrum życia duchowego każdego chrześcijanina i chrześcijańskiej miłości. Logos jest przestrzenią, w której rozwija się całe życie duchowe chrześcijanina, a zarazem najskrytszą tajemnicą mistycznych doświadczeń i miłosnych uniesień. Tajemnicą Jezusa Chrystusa - Logosu - Słowa jest też to, że rozumiemy objawione w Ewangelii Słowo Boże - rozumiemy je nie tyle w sensie teologiczno-poznawczym, ile w sensie egzystencjalnym, czyli umiemy wnieść je w nasze życie, uprzednio wypełniwszy nim swoją duszę. Słowo Boże (Logos - Jezus Chrystus) jest tajemnicą duszy chrześcijanina i tajemnicą jego życia.

28 A. L o u th, Początki mistyki chrześcijańskiej, s. 105-124; G. A. M a lo n e y, Chrystus kosmiczny. Od Pawta do Teilharda, s. 133-142. Grzegorz z Nyssy pisze, że Logos jest żywym, substancjalnym, wiecznym Słowem Boga. Ponieważ żyje, a nawet jest samym życiem, Słowo ma (jak wszystkie istoty żywe) również moc i wolną wolę. Wola Słowa Bożego jest wszechmocna, zawsze dąży do dobra i zawsze 
występuje też w teologii innych myślicieli wczesnochrześcijańskich, m.in. u Atanazego z Aleksandrii, ${ }^{29}$ Marcelego, ${ }^{30}$ Cyryla z Aleksandrii, ${ }^{31}$ a w późniejszych czasach także u Maksyma Wyznawcy, ${ }^{32}$ zwykle w kontekście wielkich tematów i kontrowersji doktrynalnych. ${ }^{33}$

Nie miejsce tu na szersze rozwijanie problemu. W każdym razie można rzec, że idea Logosu-Chrystusa, bardzo dobrze wkomponowała się w chrześcijańską wizję świata i szybko znalazła swoje miejsce w żywej, dynamicznej duchowości chrześcijańskiej. Przypomnijmy jeszcze, że myśliciele chrześcijańscy mieli tu doskonały wzór do naśladowania w twórczości Filona, żydowskiego filozofa z Aleksandrii, który zaadaptował grecką ideę Logosu do swojej filozofii Boga, inspirowanej przede wszystkim objawieniem Starego Testamentu. Logos stał się u niego Synem Boga - pośrednikiem między oddalonym od ludzi (i niedosięgłym bez pośredników) Bogiem (Jahwe) a ludźmi. Ciągle jest, jak dawniej u Greków, Umysłem, ale Umysłem mieszczącym w sobie boskie idee (wyraźnie platońska modyfikacja idei Logosu; przyjmuje ją średni platonizm i neoplatonizm). Jest też Mądrością samego Boga - tą samą Mądrością, która objawia się nam w Starym Testamencie. ${ }^{34}$ Od tak pojętego Logosu już

się ziszcza. Wszystko jest jego dziełem; św. G r z e g o r z z N y s s y, Wybór pism, Warszawa 1963, s. 60-63.

29 A. E c k m a n n, Przebóstwienie człowieka w pismach wczesnochrześcijańskich, Lublin 2003, s. 97-100; J. H. K e 11 y, Początki doktryny chrześcijańskiej, s. 184-188; J. P e l i k a n, Powstanie wspólnej tradycji, s. 211-219; A. L o u t h, Początki mistyki chrześcijańskiej, s. 101-105; G. A. M a l o n e y, Chrystus kosmiczny. Od Pawta do Teilharda, s. 117-127.

30 J. H. K e 11 y, Początki doktryny chrześcijańskiej, s. 183-184.

31 Tamże, s. 295-297; J. P e li k a n, Powstanie wspólnej tradycji, s. 238-243, 258-260; G. A. M a 1 o n e y, Chrystus kosmiczny. Od Pawła do Teilharda, s. 144-147.

32 Tamże, s. 152-154.

33 Zob. J. P el i k a n, Powstanie wspólnej tradycji, s. 179-286; E. W i p s z y c k a, Kościół w świecie późnego antyku, Warszawa 1994, s. 178-253.

34 G. R e a le, Historia filozofii starożytnej, t. IV, s. 302-304; F i 1 o n z A l e ks a n d ri i, Pisma, t. I, s. 20-26; H. i M. S i m o n, Filozofia żydowska, s. 26-34; R. M. L e s z c z y ń s k i, Starożytna koncepcja Logosu i jej wptyw na myśl wczesnego chrześcijaństwa, s. 132-172; W. J a e g e r, Wczesne chrześcijaństwo i grecka 
niedaleko do Logosu - Słowa z Prologu Ewangelii św. Jana Ewangelisty (z tym jednak zastrzeżeniem, że Filonowi obca była jakakolwiek myśl o wcieleniu Słowa). ${ }^{35}$

Filon z Aleksandrii inspirował się filozofią Logosu stoików. Logos stoików również był mądrością, myślą boską i samym Bogiem. Przenikał wewnętrzne struktury świata; był duszą tego świata, jakby jego systemem nerwowym i zarazem umysłem; był źródłem jego życiowej energii i wewnętrznym prawem jego istnienia, czyli tym, co nazywamy prawem naturalnym w szerokim znaczeniu tego słowa, także w sensie moralnym. ${ }^{36}$

paideia, s. 51; G. R e a l e, Historia filozofii starożytnej, t. IV, tłum. E. I. Z i e 1 i ń s k i, Lublin 1999, s. 302-304; J. L e g o w i c z, Filozofia okresu cesarstwa rzymskiego. Warszawa 1962, s. 79-85; F i 1 o n, O życiu Mojżesza, II 127; M. O s m a ń s k i, Logos i stworzenie. Filozoficzna interpretacja traktatu „De opificio mundi” Filona z Aleksandrii, Lublin 2001; S. M a t u s z e w s k i, Filozofia Filona z Aleksandrii i jej wpływ na wczesne chrześcijaństwo, Warszawa 1962.

35 Por. R.M. L e s z c z y ń s k i, Starożytna koncepcja Logosu i jej wptyw na myśl wczesnego chrześcijaństwa, s. 173-199. Zob. Z. P o n i t o w s k i, Logos Prologu Ewangelii Janowej, Warszawa 1970.

36 M. F a t t a 1, Między Orientem a Zachodem, tłum. P. D o m a ń s k i, Warszawa 2001, s. 42-46; G. R e a l e, Historia filozofii starożytnej, t. III, s. 331-333, 363-382; D i o g e n e s L e r tios, Żywoty i poglądy stynnych filozofów, VII 1, 88, 138-139, 142-143, Warszawa 1982, s. 410, 432, 434; R.M. L e s z c z y ń s k i, Starożytna koncepcja Logosu i jej wpływ na myśl wczesnego chrześcijaństwa, s. 79-131. Stoicy zapożyczyli ideę Logosu jeszcze od Heraklita z Efezu; zob. K. M r ó w k a, Heraklit, Warszawa 2004, s. 5-15, 19-35; K. N a r e c k i, Logos we wczesnej myśli greckiej, Lublin 1999, s. 53-94; W. J a e g e r, Teologia wczesnych filozofów greckich, s. 173-199; D. D e m b i ń s k a - S i u r y, Człowiek odkrywa człowieka. O początkach greckiej refleksji moralnej, s. 122-130; A. K r o k i e w i c z, Zarys filozofii greckiej. Od Talesa do Platona, s. 129-150; K. L e ś n i a k, Materialiści greccy w epoce przedsokratejskiej, Warszawa 1972, s. 88-94, 174-175, 183, 184; R.M. L e s z c z y ń s k i, Starożytna koncepcja Logosu i jej wpływ na myśl wczesnego chrześcijaństwa, s. 79-131. Była to ich fundamentalna idea filozoficzna, na której oparli swoją filozofię moralną i filozofię prawa. Logos stoików, tak jak Logos Heraklita, był mądrością, myślą boską i samym Bogiem usadowionym w wewnętrznych, ontycznych strukturach świata jako jego umysł i dusza, która przenika jego metafizyczną tkankę, a zarazem tkankę wszystkich rzeczy istniejących w tym świecie, tworząc coś w rodzaju naturalnego systemu nerwowego - systemu ze wszech miar racjonalnego, bo jego 
Jak już zasugerowano wcześniej, chrześcijańska idea Chrystusa jako Logosu, ze swymi odniesieniami do filozofii greckiej, miała ogromne i wielorakie znaczenie. Niezależnie od swoich implikacji teologicznych czy filozoficznych, miała z całą pewnością kolosalne znaczenie kulturowe. Przede wszystkim pozwoliła chrześcijanom dostrzec w przedchrześcijańskiej kulturze greckiej coś, co w swych pierwocinach i fundamentach jest Chrystusowe, i co samym chrześcijanom może pomóc przybliżyć się jeszcze bardziej do Chrystusa. Tymże Grekom,

rdzeniem był jednak Rozum. Logos był naturalnym i zarazem niewyczerpywalnym źródłem energii życiowej całego świata oraz wewnętrznym prawem jego istnienia, które objawia się i funkcjonuje jako prawo naturalne, zarówno w sensie przyrodniczym, jak i moralnym. W szczególny sposób ów Logos objawiała się w człowieku, a mianowicie jako jego wewnętrzny, niejako osobisty, logos (rozum), ale zarazem jako boska mądrość i prawo moralne oraz związane z nim poczucie powinności. Wyprowadzając prawo moralne z prawa natury, utożsamionego z samym Bogiem-Logosem, stoicy uznali je za boskie. W konsekwencji stało się ono czymś w rodzaju Bożej mądrości zakodowanej w jakiś sposób w strukturach bytowych ludzkiej duszy, w formie zarodkowej, w owych logoi spermatikoi, jak je nazywali filozofowie stoiccy. W filozofii stoickiej jest to o tyle jasne, że sama dusza ludzka (ludzki logos) rozumiana jest jako swego rodzaju fragment Logosu świata. Nieosobowy Logos (stoicy nigdy nie przyjęli koncepcji Boga osobowego) przenika świat od wewnątrz, egzystując w jego wewnętrznych strukturach bytowych jako jego rozumna energia życiowa i jako jego rozumne prawo bytowe (zawsze pojmowane jako od-wewnętrzne - stoicy nigdy nie przyjęli koncepcji prawa naturalnego jako czegoś zewnętrznego, transcendentnego wobec świat, tak jak nigdy nie przyjęli idei transcendencji Boga). W ten sam sposób Logos przenika człowieka, wypełnia struktury umysłowe jego duszy, i nasyca jego organizm tchnieniem życia. Człowiek, będąc częścią świata, żyje tym samem prawem, którym żyje świat. Ma jednak coś jeszcze, coś, czego poza nim nikt w świecie nie ma, a mianowicie zdolność poznania praw natury (a więc tych samych praw, którymi żyje, wraz z całym światem, i myśli). Człowiek rozpoznaje to prawo w własnej duszy. Rozpoznaje je również w świecie, w prawach przyrody. Prawo jego duszy i prawo jego ciała jest tożsame z prawem, które żyje w świecie, a ściślej - z prawem, zgodnie z którym ten świat żyje. Jest to bowiem prawo ontyczne świata, czyli prawo wpisane w jego tkankę bytową. Jest ono naturalnym sposobem egzystowania świata. Bardzo ważne w stoickiej koncepcji prawa naturalnego jest stwierdzenie jego racjonalności (i boskości). Racjonalność jest immanentną własnością natury świata. 
z kolei, pozwoliła niejako bezboleśnie przyjąć chrześcijaństwo nie jako coś zupełnie obcego ich kulturze, lecz jako jej uzupełnienie i wypełnienie (wypełnienie tego, co w ich własnej kulturze duchowej wprawdzie zakiełkowało, ale oczekuje i domaga się dopełnienia w Chrystusie). Tym samym chrześcijaństwo przestało być czymś obcym, a grecka kultura przestała być obca chrześcijanom. Dostrzeżenie w tej kulturze owoców działania Logosu-Chrystusa, stworzyło teoretyczną podstawę jej akceptacji, a nawet adaptacji do chrześcijaństwa. Z drugiej strony „pogańskim” Grekom pozwoliła dostrzec w chrześcijaństwie jakby naturalne dopełnienie czegoś, na co ich kultura była niejako od zarania duchowo nastawiona. ${ }^{37}$

Słowa kluczowe: chrześcijaństwo, kultura grecka, Justyn Męczennik, Klemens Aleksandryjski, filozofia

Keywords: Christianity, Greek culture, Justin Martyr, Clement of Alexandria, philosophy

\section{The Encounter of Early Christianity with Greek Pagan Philosophy in the Second Century CE (In Times of Justin Martyr and Clement of Alexandria)} Summary

For followers of religions which take solid cultural form of coherent doctrinal systems, the fact that other comparable religious systems exist may pose a difficult theoretical and existential problem that needs to be addressed at a number of levels, including the one of human existential experience. This is the problem that was faced by the original followers of the Christian religion in relation to the Greek spiritual culture, and ancient Greek philosophy in particular, at the time when it boldly explored spiritual areas closely connected to Christianity. The problem became particularly significant in the second century CE. It was tackled by early Christian thinkers that were educated in Greek philosophy themselves and used its ideas to solve the above-mentioned problem.

37 Por. E. D o d d s, Pogaństwo i chrześcijaństwo w okresie niepokoju. Niektóre aspekty doświadczenia religijnego od Marka Aureliusza do Konstantyna Wielkiego, s. $101-128$. 